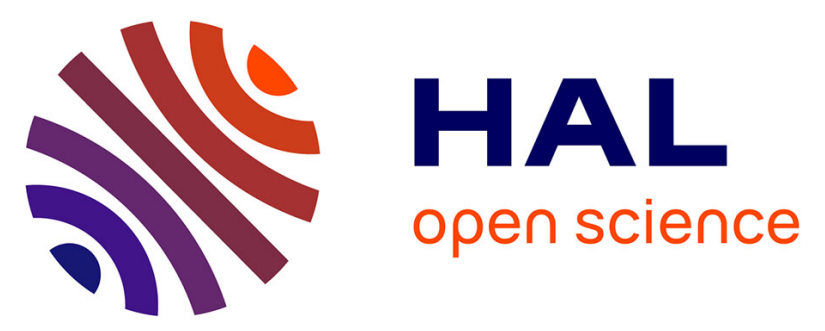

\title{
Detecting stratigraphical issues using direct radiocarbon dating from small-mammal remains
}

Juan Rofes, Sophie Cersoy, Antoine Zazzo, Aurélien Royer, Pierre-yves Nicod, Véronique Laroulandie, Mathieu Langlais, Yvan Pailler, Céline Leandri, Franck Leandri, et al.

\section{To cite this version:}

Juan Rofes, Sophie Cersoy, Antoine Zazzo, Aurélien Royer, Pierre-yves Nicod, et al.. Detecting stratigraphical issues using direct radiocarbon dating from small-mammal remains. Journal of Quaternary Science, 2020, 35 (4), pp.505-513. 10.1002/jqs.3193 . hal-02569726

\section{HAL Id: hal-02569726 https://hal.science/hal-02569726}

Submitted on 9 Nov 2020

HAL is a multi-disciplinary open access archive for the deposit and dissemination of scientific research documents, whether they are published or not. The documents may come from teaching and research institutions in France or abroad, or from public or private research centers.
L'archive ouverte pluridisciplinaire HAL, est destinée au dépôt et à la diffusion de documents scientifiques de niveau recherche, publiés ou non, émanant des établissements d'enseignement et de recherche français ou étrangers, des laboratoires publics ou privés. 


\section{Detecting stratigraphical issues using direct radiocarbon dating from small-mammal remains}

\section{Running title: Radiocarbon dating small mammal remains}

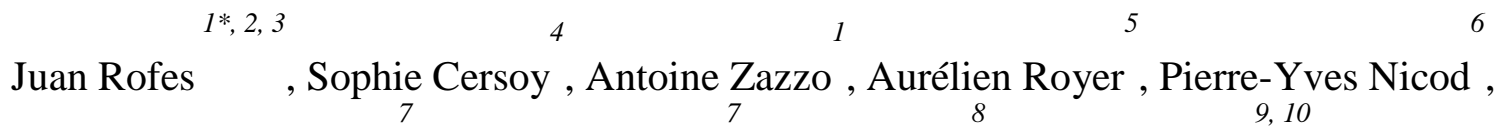

Véronique Laroulandie , Mathieu Langlais , Yvan Pailler, Céline Leandri ，Franck

Leandri , Matthieu Lebon , Anne Tresset

${ }^{1}$ Archéozoologie, Archéobotanique: Sociétés, Pratiques et Environnements (AASPE, UMR 7209), Sorbonne Universités, Muséum national d'Histoire naturelle, CNRS, CP56, 55 rue Buffon, F75005 Paris, France.

*juan.rofes@mnhn.fr

${ }^{2}$ Archaeological Studies Program, University of the Philippines. Albert Hall, Lakandula St., UP Diliman, Quezon City 1101, Philippines. Philippines.

${ }^{3}$ Research Associate, National Museum of the Philippines. P. Burgos Drive, City of Manila,

${ }^{4}$ Centre de Recherche sur la Conservation (CRC), Muséum national d'Histoire naturelle, CNRS, Ministère de la Culture, 36 rue Geoffroy Saint Hilaire, 75005, Paris, France.

${ }^{5}$ Biogéosciences, UMR 6282 CNRS, Université Bourgogne Franche-Comté, EPHE, 6 Boulevard Gabriel, 21000 Dijon, France.

${ }^{6}$ Laboratoire d'archéologie préhistorique et anthropologie, Université de Genève, Institut F.A. Forel, 66 Boulevard Carl Vogt, CH-1211 Geneva 4, Switzerland.

${ }^{7}$ PACEA, UMR 5199 du CNRS, Université de Bordeaux, Bâtiment B2, Allée G. SaintHilaire, CS 50023, 33615 Pessac cedex, France.

${ }^{8}$ INRAP, UMR 8215 Trajectoires, LTSER France, Zone Atelier «Brest-Iroise», Institut Universitaire Européen de la Mer, Rue Dumont d'Urville, Technopôle Brest Iroise, 29280 Plouzané, France.

${ }^{9}$ DRAC, Service de l'Archéologie de Corse, 1, chemin de la Pietrina, CS 10003, 20704 Ajaccio cedex 9, France.

${ }^{10}$ UMR 5608, TRACES, Maison de la Recherche, Université Toulouse Jean Jaurès 5 allées A. Machado, 31058 Toulouse, Cedex 9.

${ }^{11}$ Histoire Naturelle de l'Homme Préhistorique (HNHP), Muséum National d'Histoire Naturelle, UMR 7194 CNRS, Université Perpignan Via Domitia, 17 Place du Trocadéro, 75116 Paris, France.

$\dagger$ Deceased. 


\begin{abstract}
Frequently preserved in archaeological and paleontological sites, the tiny size of smallmammal remains favors percolations into underlying layers along stratigraphic sequences. This is one of the multiple post-depositional processes that may affect the integrity of the original deposits and therefore the subsequent scientific interpretations. Recent developments in sample preparation offer the possibility of detecting intrusive episodes through the absolute dating of minute amounts of bone (down to $10 \mathrm{mg}$ ), meaning that isolated elements (such as mandibles in this case) are sufficient to obtain reliable radiocarbon dates if collagen is moderately to well preserved. The radiocarbon dates obtained here for small-mammal bones (recovered from pre-Bølling to recent deposits) and their comparison with previous dates obtained from other sources (large-mammal bones, charcoal, botanical samples, etc.), with different protocols and instruments, illustrate the potential of small-mammal dating to reveal (and eventually contribute a solution to) stratigraphical issues in different archaeological contexts.
\end{abstract}

Keywords: archaeology; absolute dates; small mammals; stratigraphic sequences; intrusive episodes. 
ROFES J., CERSOY S., ZAZZO A., ROYER A., NICOD P.-Y., LAROULANDIE V., LANGLAIS M., PAILLER Y., LEANDRI C., LEANDRI F., LEBON M TRESSET A., 2020 - Detecting stratigraphical issues using direct radiocarbon dating from small-mammal remains. Journal of Quaternary Science, 35(4), pp. 505-513.

\section{Introduction}

Small-vertebrate remains are frequently preserved in archaeological and palaeontological deposits such as caves and rock shelters, sometimes in association with human remains and artifacts. Contrary to their larger counterparts, which are usually a product of human selection, the small-vertebrate accumulations mainly result from digestion or storing by their predators (i.e., birds of prey, small carnivores). Despite unavoidable filters due to specific predators (e.g., Mellet, 1974; Andrews, 1990), they reasonably well reflect local biocenoses. Presence/absence and relative abundances of small-mammal species can thus be used as proxies for biochronology (e.g., Cuenca-Bescós et al., 2010, 2015) and for the reconstruction of both past environments (e.g., López-García et al., 2014; Rofes et al. 2014, 2015; Royer, 2016) and biogeographical histories (e.g., Cucchi et al., 2014; Rofes et al., 2018).

Such interpretations are based on the working hypothesis of a strict association between small vertebrates and archaeological remains, implying a good archaeological coherence of the analyzed assemblages. However, this is not always the case. Multiple kinds of postdepositional processes can affect the stratigraphy of a given site by altering the integrity of the deposits (e.g., Wood and Lee Johnson, 1978; Texier, 2000) and therefore the subsequent scientific interpretations. For instance, caves and rock shelters are propitious places for small and medium size animals to nest or build burrows, which may significantly modify and pollute faunal assemblages (Dalland and Carter, 1998; Mallye, 2011; Pelletier et al., 2016).

Absolute dates are crucial for the reconstruction of past environments: they constitute diachronic anchors for the signals tracing the evolution of climate and habitats in a given location. They are also essential for biochronology and biogeography, to explore the accuracy of chronological biomarkers, in the first case, and to test the reliability of previous hypothesis (e.g., from phylogeography), in the second. Finally, they allow the evaluation of faunal assemblages regarding the contemporaneity of archaeological remains and species (e.g., Costamagno et al., 2016; Pelletier et al., 2017; Royer et al., 2018).

Accelerator mass spectrometers (AMS) have revolutionized the field of archaeology since their inception, allowing absolute dates to be obtained for the last $50 \mathrm{ky}$ (Reimer et al., 2013). However, routine AMS dating still requires 60-200 mg of bone, depending on preservation state, which far exceeds the mass of isolated elements of the skeleton of many small mammals, such as rodents, shrews and bats. Here, we present 15 radiocarbon dates obtained from minute amounts of bone (less than $25 \mathrm{mg}$ ) of small mammals, using a Mini Carbon 
Dating System (MICADAS) and following a recently developed optimized protocol (Cersoy et al., 2017a, 2017b). The samples come from four archaeological sites with different chronologies, chrono-culturally spanning from the upper Magdalenian to recent times. We compare these new dates with previous ones obtained from different materials (e.g., largeand small mammal bones, charcoal, plants) in different laboratories, using other protocols, to check for agreements. Departing from this comparison, our purpose is to evaluate how and to what extent this new procedure can detect stratigraphical issues in archaeological sequences and contribute to their solution.

\section{Materials and Methods}

\section{Archaeological sites}

The following sites are all located in rock shelters at different altitudes, with the exception of Beg ar Loued, which is an open-air household settlement next to the coast. The location of the sites is shown in Figure 1.

The site of Peyrazet (Creysse, Lot) has five stratigraphic levels, chronologically spanning from the pre-Bølling period (end of Heinrich Stadial 1) to the Preboreal. The site contains archaeological material from the recent Laborian (=Final Paleolithic; a lithic techno-complex occurring during the transition between the Younger-Dryas and the Preboreal in southwest France [Langlais et al., 2015]), the Azilian (during the Allerød chronozone), and the Upper Magdalenian (during the Bølling) (Langlais and Laroulandie, 2016). Eight radiocarbon dates from reindeer, roe deer and water vole bones confirmed this chronology (Langlais et al., 2015; Costamagno et al., 2016; Royer, 2016).

The settlement of Beg ar Loued (Molène Island, Brittany) was built during the Early Bronze Age. The radiocarbon dated shrew mandible here comes from the infill of a dry-stone oval building, which, according to several radiocarbon dates obtained from other sources (charcoal and large-mammal bones for the most part), was likely occupied from 2200 to 1800 years cal BC (Pailler et al., 2014, 2019).

The rock shelter of Lano (Castagnicia, Haute-Corse, Corsica) was used for funerary purposes, as revealed by the presence of three wooden coffins found inside. The coffins contained human remains dating to the Bronze Age, based on radiocarbon dating of the 
human bones and wood from a coffin (Leandri et al., 2016). In 2016, a test pit was conducted at roughly $2 \mathrm{~m}$ from the entrance of the cave. The stratigraphic section was divided into stratigraphic units (US), which, from bottom to top of the sequence, were named US 12 to US 5. The layers D1-D5, from a previous test pit made in 2015, were correlated with US 5 and 6 of this new stratigraphy, being D1 the uppermost and D5 the lowest.

The Grande Rivoire site (Sassenage, Isère, Auvergne-Rhône-Alpes) has been divided in several excavation sectors. The small mammal remains dated in this study come from the NR16-21 and SU16-22 sectors. They comprise five different chrono-cultural units, listed here from earliest to latest: Second Mesolithic, transition from Second Mesolithic to Early Neolithic, Early Neolithic, Middle Neolithic 1 and Middle Neolithic 2. These units were subdivided in turn into subunits ("décapages") and several radiocarbon dates from charcoal, large-mammal bones, seeds and hazelnut were obtained for them, all supporting the chronology (Rofes, 2018).

\section{Samples}

Fifteen mandibles of shrews (Soricidae, Mammalia) from the above-mentioned locations have been radiocarbon dated (Table 1). The mandibles belong to the species Crocidura suaveolens, C. russula, C. leucodon, Neomys anomalus and Sorex gr. araneus-coronatus, weighing between 10.5 and $25.0 \mathrm{mg}$ as displayed in Table 2. They were part of natural accumulations of small vertebrates, mainly contributed by birds of prey (i.e., rejection pellets). The taxonomical identifications were performed by one of us (JR), based on diagnostic morphological characters.

\section{Sample selection: optimized sample yield and ATR-FTIR estimation of collagen content}

Prior to radiocarbon dating, we estimated the collagen content of the samples using attenuated total reflectance Fourier transform infrared spectroscopy (ATR-FTIR), following the procedure described in Lebon et al. (2016). Due to their small size, only three samples could be examined (JR1, JR 16 and JR 24, Table 1). Briefly, less than one mg of crushed bone was placed on the diamond ATR accessory (Golden Gate Single Reflection Diamond 
ATR accessory, Specac, France) and analysed with a Vertex 70 FT-IR spectrometer (Bruker Optics, France).

ATR spectra (Figure 2) were obtained by the accumulation of 128 scans in the wavenumber range $4000-400 \mathrm{~cm}^{-1}$ with a spectral resolution of $2 \mathrm{~cm}^{-1}$. During acquisition, $v_{3} \mathrm{PO}_{4}$ peaks were normalized to an absorbance of 0.5. Data treatment (linear baseline correction and amide I /phosphate $v_{3}\left(\mathrm{PO}_{4}\right)$ bands measurement) was performed using OPUS software (Bruker Optics, France). Collagen contents were estimated from the amide $\mathrm{I} / \mathrm{PO}_{4}$ ratio using equations reported in Lebon et al. (2016), taking standard deviations into account. Note that this method is not reliable for quantification below the $4 \%$ yield threshold, and collagen detection is impossible below $3 \%$.

The amount of bone sample needed to perform the radiocarbon date can be predicted using a chart (Figure 3). In the $\mathrm{X}$-axis, the collagen yield in \% is reported. Using the $0.2 \mathrm{mgC}$ curve, which is the threshold for the commercially available AGE3 graphitization unit, the minimum amount of bone required for a radiocarbon date can be read on the Y-axis. Two more curves are reported, corresponding to $0.5 \mathrm{mgC}$ and $1 \mathrm{mgC}$ : they show the limit for radiocarbon dating on (more widespread) conventional AMS. This limit gives the amount of bone needed at worst to obtain a radiocarbon date: $18 \mathrm{mg}$ for MICADAS dating (after graphitization) and $40 \mathrm{mg}$ for conventional AMS dating. On the other hand, maximum collagen content in modern fresh bones is indicated (20-25\%) (Schoeninger et al., 1989).

Collagen content for the three samples varies between 5.2 and $8.0 \%$ indicating that a minimum amount of 6.3 to $9.6 \mathrm{mg}$ of bone is required, if all the bone collagen content is extractible (meaning that the collagen content is equal to the collagen extraction yield), to obtain the minimum $0.2 \mathrm{mg}$ of carbon for radiocarbon dating analysis on ECHoMICADAS (dotted curve). As mandibles weighed between 10.5 and $25 \mathrm{mg}$ (as stated in Table 2), we applied the extraction protocol to all the samples.

\section{Collagen extraction and radiocarbon dating}

Collagen extraction and radiocarbon dating were performed following Cersoy et al. (2017a, 2017b). Briefly, mandibles were immersed in $0.2 \mathrm{M}$ hydrochloric acid at $4{ }^{\circ} \mathrm{C}$ for 2 days to perform demineralization. The remaining decalcified collagen was rinsed with Milli-Q water and purified in $0.1 \mathrm{M} \mathrm{NaOH}$ at $4{ }^{\circ} \mathrm{C}$ for 2 days to eliminate soil contaminants. Finally, 
collagen was rinsed with $0.2 \mathrm{M} \mathrm{HCl}$ and then Milli-Q water before gelatinization in $0.06 \mathrm{M}$ hydrochloric acid at $90{ }^{\circ} \mathrm{C}$ for one hour, and purification by glass filtering. For this last step, specific glass vacuum filtration devices, with 1.6 microns maximum pore size, where designed and manufactured by Ellipse (France). Freeze-dried collagen was transferred to tin capsules after resuspension in ultrapure water and combustion was performed in an Elemental Analyzer (EA). All samples, except JR 15, were graphitized on the commercial compact graphitization system AGE 3 (Ion plus, Switzerland) (Wacker et al., 2010a). Due to the low amount of collagen extracted from JR 15 bone sample, a gas interface system (GIS) was used (Wacker et al., 2013). Following combustion in the EA, sample $\mathrm{CO}_{2}$ was adsorbed on a zeolite trap before being released and expanded to the syringe of the GIS (Ruff et al., 2010; Wacker et al., 2013). For all samples, dating was performed on the compact AMS ECHoMICADAS at Gif-sur-Yvette (France) (Wacker et al., 2010b).

\section{Results}

The radiocarbon dates of the samples are reported in Table 2. Collagen yields range between 3.1 and $15.4 \%$, above the $1 \%$ threshold for datable samples, confirming the moderately to good preservation of the collagen in the bone samples. We were thus able to extract enough collagen for radiocarbon dating (corresponding to 0.188 to $0.862 \mathrm{mgC}$ ). $\mathrm{C} / \mathrm{N}$ ratios range between 3.2 and 3.6, within the 2.9-3.6 limits suitable for radiocarbon dating (DeNiro, 1985; Van Klinken, 1999).

\section{Peyrazet}

Comparing the dates in this study with those previously obtained for Level 4 and Level 2 (Table 3), we observe that, with regard to Level 4, there is an agreement between our dates $(12940 \pm 7014 \mathrm{C}$ a BP, $12960 \pm 7014 \mathrm{C}$ a BP) and the one previously performed on a selection of water vole (Arvicola sp.) bones dated altogether (12960 \pm 70 14C a BP; Royer, 2016) in another laboratory (Lyon) with conventional extraction and classical AMS dating. The rest of the dates available for this unit (Ly-6437 to Ly-13447 in Table 3) are also consistent with the new ones and with the chrono-cultural attribution (Upper Magdalenian).

However, there is a significant difference in Level 2 between our dates $(1585 \pm 3014 \mathrm{C}$ a BP, $1475 \pm 3014 \mathrm{C}$ a BP) and the one previously performed on a metapodial of red deer (Cervus 
elaphus) considered to be in situ (9780 \pm 45 14C a BP; Langlais et al., 2015). Another date newly obtained for the site $(11790 \pm 23014 \mathrm{C} \mathrm{a} \mathrm{BP})$ is also in agreement with a previous one obtained for a roe deer (Capreolus capreolus) metacarpal (11810 $\pm 5014 \mathrm{C}$ a BP), both remains from the same stratigraphical interface between levels 3 and 4 .

\section{Beg ar Loued}

A mandible of Neomys anomalus gave a date of 3650 \pm 30 14C a BP (ECHo-1258). This date is somewhat older than a previous one, performed on a Microtus agrestis mandible $(3177 \pm 35$ 14C a BP, UB-6925) found in the same scree layer inside the house (Table 3) (Pailler et al., 2019).

\section{Lano}

The comparison of our dates (Table 3) for layers D4 (post-bomb) and D1 (515 \pm 20 14C a BP) with those previously obtained from the Poznan Radiocarbon Laboratory for layers D5 (postbomb) and D3 (1155 \pm 30 14C a BP), the latter two from selections of small-vertebrate bones with a different technique, allows us to state that: 1) layers D1 and D3 are in good stratigraphical order, D1 dating to the 15 th century and D3 to the 8th-10th centuries; 2) D4 and D5 are modern; 3) these data in turn allow to infer that the sequence D5-D1 presents a "stratigraphic inversion", where layers D4 and D5 are more recent than D3-D1; and 4) considering that the US 6 and 5 nearly coincide with layers D5-D1 (see Lano section on Materials and Methods), these units may also present a stratigraphic inversion.

\section{Grande Rivoire}

Comparing our seven dates to the corpus previously obtained from other materials (i.e., largemammal bones, charcoal, plants), by different laboratories (Lyon-Saclay and Beta Analytics), we observe that they all agree with the general chronostratigraphic framework. Some of our

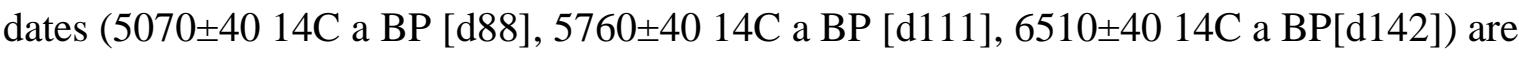
almost identical to those already obtained on the same layers (see Table 4), whereas others

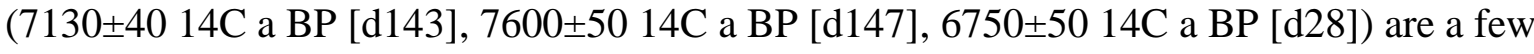
centuries older without being in contradiction with the general framework. Finally, it should be noticed that the date obtained for the layer d22 of the sector SU16-22 (6410 $44514 \mathrm{C}$ a 
BP), attributed to the early Neolithic by the excavators, is also coherent with that of the layer d26 (6510 \pm 40 14C a BP), which is directly underlying.

It should be noted that three of the oldest dates appear to have a higher $\mathrm{C} / \mathrm{N}$ ratio, above 3.5 . Nonetheless, hardly this can explain the discrepancy observed for two reasons: (1) usually, contamination makes the sample appear younger (and not older) because contaminants come from the soil organic matter whose $14 \mathrm{C}$ activity is younger than the bone remains (as recently demonstrated in Zazzo et al., 2019) and (2) other samples have also high $\mathrm{C} / \mathrm{N}$ ratio but they are in good agreement with the paired date, like, for instance, JR 16 (from Peyrazet, described above), which is older and therefore more prone to contamination. Hence, we think the discrepancy observed is rather due to a stratigraphic issue at Grande Rivoire rather than to contamination. 


\section{Discussion}

In Peyrazet, the perfect agreement between the new dates and those previously obtained in another laboratory for Level 4 (Upper Magdalenian) confirms the reliability of the new protocol. At the same time, these direct dates attest the oldest postglacial presence of $N$. anomalus in western Europe (see Table 3). The two dates from the interface between Levels 4 and 3 (Upper Magdalenian/Azilian), confirm one another despite the large uncertainty associated with our measurement $( \pm 23014 \mathrm{C}$ a) for the mandible of $C$. $\mathrm{cf}$. suaveolens (due to the low amount of extractible collagen). To our knowledge, this is the oldest direct postglacial evidence (i.e., 14175-13129 cal a BP) for this taxon in western Europe up to now, giving an age well within the Bølling-Allerød warm pulse (c. 14700 to c. 12700 a BP). Notably, it confirms a recently proposed scenario for the postglacial recolonization of this species from the Iberian Peninsula (Rofes et al., 2018). There is a notorious lack of absolute dates for small mammal taxa to support postglacial recolonization models inferred by other means (e.g., molecular phylogeography), thus those recently obtained for the N. anomalus and $C$. cf. suaveolens of Peyrazet will certainly be of great biogeographical and biochronological value.

The difference between our dates and those previously obtained regarding Level 2, can be explained by the presence of bioturbation in upper deposits. The archaeological materials seem relatively homogeneous from a cultural standpoint, although protohistoric ceramics have been found in these upper levels (Langlais et al., 2015). The integrity of the small vertebrate assemblages was questioned due to the association of black rat (Rattus rattus) and European hamster (Cricetus cricetus) remains (Langlais et al., 2015). If the first species is clearly not attested in France before the Antiquity (Pascal et al., 2006), the second one suggests that these materials could be Younger-Dryas in origin, as it has been recently demonstrated for the hamster remains in Combe Cullier (Royer et al., 2018). The recent radiocarbon dates obtained from the two shrew remains (c. $5^{\text {th }}-7^{\text {th }}$ centuries AD) thus strongly suggest the presence of more recent intrusive remains in this level, presumably brought from upper layers by burrowing activities. Further inferences made from this level should then be taken with caution.

Figure 4 displays the stratigraphy of Peyrazet (4A) and synthetizes all our findings (4B), including agreements and disagreements among dates. 
The discrepancy of dates in Beg ar Loued may be due to the different periods in which the remains were naturally deposited inside the structure. The Neomys mandible could date from the foundation of the building during the Early Bronze Age, whereas the Microtus mandible could date from the time of abandonment of the household during the Middle Bronze Age. There are several potential reasons for their coexistence in the same scree level, including the activity of burrowing animals. Another straightforward explanation is that the shrew mandible was deposited over an elevated stone-wall which posteriorly crumbled.

In Lano, the presence of $R$. rattus in the lowermost levels of the sequence (US 12), indicates that the accumulation postdates the $4^{\text {th }}-2^{\text {nd }}$ centuries $\mathrm{BC}$, a period during which the black rat was introduced into Corsica (Pascal et al., 2006). The absence of endemic taxa, such as Prolagus, Asoriculus, Rhagamys or Tyrrenicola, also indicates that this deposit is contemporary or postdates the extinction of the native fauna of the island between the $2^{\text {nd }}$ and the $13^{\text {th }}$ centuries AD. The stratigraphic sequence studied is thus clearly posterior to the deposit of the wooden coffins, which date from the first millennium BC (Leandri et al., 2016). It is too early to propose an explanation regarding the "stratigraphical inversion" detected. Works on the site continues and excavators will be reaching the end of the cavity soon. That will allow identification of the initial area of the deposit and perhaps the reason for the inversion, a phenomenon which is not surprising given the complexity of sedimentary processes in caves.

In Grande Rivoire, the seven ECHo dates are consistent with the general chrono-stratigraphy of the deposit (see Table 4 where they are displayed in stratigraphic order), even if there are three (ECHo-1247, ECHo-1696 and ECHO-1702) which are older ( 3 centuries) than the measurements made on hazelnuts (Lyon-13971 and Lyon-13972) or bones (Beta 28246 and Beta-255118) from the same levels. For the two results dating back to the Mesolithic/ Neolithic transition (ECHo-1247 and ECHo-1702), the lag of a few centuries could be due to the slow formation of the levels in question, well evidenced by the sedimentological analyzes (Nicod et al., 2012). However, the good general coherence between the new dates and those previously obtained with other techniques, accredits also in this case the reliability of the new protocols. Moreover, these new dates show that the natural accumulations of small vertebrates in the different units do not result from modern contamination or postsedimentary rearrangements. They instead come from in situ accumulations contemporary to the formation of the deposits. This validates any further stratigraphic, biogeographical and/or palaeoenvironmental interpretation made from the small-mammal associations of this site. It 
should be mentioned that the dates obtained from charred hazelnuts (layers d143 and d147) are clearly more recent than the new dates from the same layers. This might be explained either by contamination or intrusions from upper units.

\section{Conclusions}

The radiocarbon dates obtained here for small-mammal bones and their comparison with previous dates obtained from other sources (e.g., large-mammal and other small-vertebrate bones, charcoal, botanical samples, etc.), with different protocols and instruments, show the potential of small-vertebrate dating to reveal (and eventually contribute a solution to) stratigraphical issues in different archaeological contexts, from pre-Bølling to recent times.

Our results show that chronological, environmental and/or biogeographical inferences based on the small-mammal assemblages from Levels 3 and 4 of Peyrazet, and the entire stratigraphical sequence of Grande Rivoire, are trustworthy. We cannot state the same for Level 2 of Peyrazet, the infill of the structure of Beg ar Loued, or the stratigraphy of Lano. Caution is advisable in the latter cases.

The tiny size of small-mammal remains favors percolations into underlying layers along stratigraphic sequences: this is a well-known phenomenon in archaeological deposits. The new technique offers a straightforward possibility of detecting intrusive episodes through the absolute dating of minute amounts of bone (down to $10 \mathrm{mg}$ in this study), meaning that isolated elements (such as shrew mandibles in this case) are enough to obtain reliable radiocarbon dates if collagen is moderately to well preserved. Besides, this technique is far less destructive than previous ones, which require a minimum of $60 \mathrm{mg}$ of bone to obtain results, meaning collections of bones of small vertebrates with the possible admixture of noncontemporaneous materials. Moreover, for bones of sufficient size, an ATR-FTIR prescreening can estimate quickly, with just $1 \mathrm{mg}$ of bone, whether a sample contains sufficient collagen to be successfully radiocarbon dated or not, well before any further extraction or intense laboratory pretreatment. 


\section{Acknowledgments}

This paper is dedicated to the memory of our courageous colleague Anne Tresset, who contributed the seminal idea for the research and who sadly passed away in January 2019, during the writing of the manuscript.

The research was accomplished through the financial support of a Marie Curie IntraEuropean Fellowship (PIEF-GA-2013-629604 of the European Commission) from which JR was the Fellow and AT the scientist in charge. JR is also a member of the Atapuerca Project PGC2018-093925-B-C33 (MINECO, Spain). Peyrazet field work obtains financial support from DRAC-SRA Occitanie and Conseil Général du Lot.

The work was also supported by a State aid, managed by the French National Research Agency (ANR), namely LabEx ANR-10-LABX-0003-BCDiv, within the framework of “Investissements d'avenir" program number ANR-11-IDEX-0004-02. We are also very grateful to C. Gauthier, E. Kaltnecker, F. Thil and N. Tisnerat-Laborde, from the ECHoMICADAS team, for the radiocarbon dates (graphitization, AMS measurements and data reduction). Fiona Brock and another anonymous reviewer substantially contributed to improve the paper.

\section{References}

Andrews P. 1990 Owls, Caves and Fossils: Predation, Preservation and Accumulation of Small Mammal Bones in Caves, with an Analysis of the Pleistocene Cave Faunas from Westbury-SubMendip, Somerset, U.K. University of Chicago Press: Chicago.

Cersoy S, Zazzo A, Lebon M, Rofes J, Zirah S. 2017a. Collagen Extraction and Stable Isotope Analysis of Small Vertebrate Bones: A Comparative Approach. Radiocarbon 59: 679-694. [https://doi.org/10.1017/RDC.2016.82].

Cersoy S, Zazzo A, Rofes J, Tresset A, Zirah S, Gauthier C, Kaltnecker E, Thil F, Tisnerat-Laborde $\mathrm{N}, 2017 \mathrm{~b}$. Radiocarbon dating minute amounts of bone (3-60 mg) with ECHoMICADAS. Scientific Reports 7: 7141. [https://doi.org/10.1038/s41598-017-07645-3].

Costamagno S, Barshay-Szmidt C, Kuntz D, Laroulandie V, Pétillon J-M, Boudadi-Maligne M, Langlais M, Mallye J-B, Chevallier A. 2016. Reexamining the timing of reindeer disappearance in southwestern France in the larger context of late glacial faunal turnover. Quaternary International 414: 34-61. [https://doi.org/10.1016/j.quaint.2015.11.103].

Cucchi T, Barnett R, Martínková N, Renaud S, Renvoisé E, Evin A, Sheridan A, Mainland I, Wickham-Jones C, Tougard C, Quéré JP, Pascal Mi, Pascal Ma, Heckel G, O’Higgins P, Searle JB, 
Dobney KM. 2014. The Changing Pace of Insular Life: 5000 Years of Microevolution in the Orkney Vole (Microtus arvalis orcadensis). Evolution 68: 2804-2820. [https://doi.org/10.1111/evo.12476].

Cuenca-Bescós G, Blain H-A, Rofes J, Lozano-Fernández I, López-García JM, Duval M, Galán J, Núñez-Lahuerta C. 2015. Comparing two different Early Pleistocene microfaunal sequences from the caves of Atapuerca, Sima del Elefante and Gran Dolina (Spain): Biochronological implications and significance of the Jaramillo subchron. Quaternary International 389: 148-158.

[https://doi.org/10.1016/j.quaint.2014.12.059].

Cuenca-Bescós G, Rofes J, López-García JM, Blain H-A, De Marfá, RJ, Galindo-Pellicena MA, Bennásar-Serra ML, Melero-Rubio M, Arsuaga JL, Bermúdez de Castro JM, Carbonell E. 2010. Biochronology of Spanish Quaternary small vertebrate faunas. Quaternary International 212: 109119. [https://doi.org/10.1016/j.quaint.2009.06.007].

Dalland M, Carter S. 1998. The evaluation of a prehistoric mound damaged by rabbit burrowing at Maryton Law, Angus. Tayside Fife Archaeological Journal 4: 20-30.

DeNiro MJ. 1985. Postmortem preservation and alteration of in vivo bone isotope ratios in relation to palaeodietary reconstruction. Nature 317: 806-809.

Mallye J-B. 2011. Badger (Meles meles) remains within caves as an analytical tool to test the integrity of stratified sites: the contribution of Unikoté Cave (Pyrénées-Atlantiques, France). Journal of Taphonomy 9: 15-36.

Mellet JS. 1974. Scatological origin of microvertebrate fossil accumulations. Science 185: 349-350.

Nicod P-Y, Perrin T, Brochier J-L, Chaix L, Marquebielle B, Picavet R, Vannieuwenhuyse D. 2012. Continuités et ruptures culturelles entre chasseurs mésolithiques et chasseurs néolithiques en Vercors: analyse préliminaire des niveaux du Mésolithique récent et du Néolithique ancien sans céramique de l'abri-sous-roche de la Grande Rivoire (Sassenage, Isère). In Dynamismes et rythmes évolutifs des sociétés de la Préhistoire récente. Actualité de la recherche, Perrin T, Cauliez J, Sénépart I, Thirault E, Bonnardin S (eds.). 9e Rencontres Méridionales de Préhistoire Récente. Toulouse: Archives d'Écologie Préhistorique; 13-32.

Langlais M, Laroulandie V. 2016. La grotte-abri de Peyrazet (Creysse, Lot, France): une séquence tardiglaciaire pour le Quercy. Annales des XXIVe Rencontres archéologiques de Saint-Céré (Lot) 23: 63-67.

Langlais M, Laroulandie V, Jacquier J, Costamagno S, Chalard P, Mallye J-B, Pétillon J-M, Rigaud, S, Royer A, Sitzia L, Cochard D, Dayet L, Fat Cheung C, Le Gall O, Queffelec A, LacrampeCuyaubère F, 2015. Le Laborien récent de la grotte-abri de Peyrazet (Creysse, Lot, France). Nouvelles données pour la fin du Tardiglaciaire en Quercy. PALEO 26: 79-116.

Leandri F, Bressy-Leandri C, Galant P, Courtaud P, Vigne J-D, Milza, J-CL, Courtois J-Y, Ferraz, AL, Genevier, M, Bernard-Maugiron, H, Marini, N, Peche-Quilichini, K, Seguin, M, Tramoni, P. 2016. La cavité sépulcrale de Laninca (Lano, Haute-Corse) (report). DRAC-SRA: Corse.

Lebon M, Reiche I, Gallet X, Bellot-Gurlet L, Zazzo A. 2016. Rapid Quantification of Bone Collagen Content by ATR-FTIR Spectroscopy. Radiocarbon 58: 131-145.

[https://doi.org/10.1017/RDC.2015.11]. 
López-García JM, Berto C, Colamussi V, Dalla Valle C, Lo Vetro D, Luzi E, Malavasi G, Martini F, Sala B. 2014. Palaeoenvironmental and palaeoclimatic reconstruction of the Latest PleistoceneHolocene sequence from Grotta del Romito (Calabria, southern Italy) using the small-mammal assemblages. Palaeogeography, Palaeoclimatology, Palaeoecology 409: 169-179.

Pailler Y, Stéphan P, Gandois H, Nicolas C, Sparfel Y, Tresset A, Donnart K, Dréano Y, Fichaut B, Suanez S, Dupont C, Audouard L, Marcoux N, Mougne C, Salanova L, Sellami F, Dietsch-Sellami, M-F. 2014. Landscape Evolution and Human Settlement in the Iroise Sea (Brittany, France) during the Neolithic and Bronze Age. Proceedings of the Prehistoric Society 80: 105-139.

[https://doi.org/10.1017/ppr.2014.9].

Pailler Y, Nicolas C, Gandois H, Tresset A. 2019. Datations absolues et comparaisons chronologiques. In Une maison sous les dunes: Beg ar Loued, Ile Molène, Finistère. Identité et adaptations des groups humaines en mer d'Iroise à la transition des IIIe-IIe millénaires avant notre ère, Pailler Y, Nicolas C (eds). Ed. Sidestone press: Leiden; 291-312.

Pascal M, Lorvelec O, Vigne J-D. 2006 Invasions biologiques et extinctions : 11000 ans d'histoire des vertébrés en France. Belin.

Pelletier M, Brugal J-P, Cochard D, Lenoble A, Mallye J-B, Royer A. 2016. Identifying fossil rabbit warrens: Insights from a taphonomical analysis of a modern warren. Journal of Archaeological Science: Reports 10: 331-344. [https://doi.org/10.1016/j.jasrep.2016.10.016].

Pelletier M, Royer A, Holliday TW, Discamps E, Madelaine S, Maureille B. 2017. Rabbits in the grave! Consequences of bioturbation on the Neandertal "burial" at Regourdou (Montignac-surVézère, Dordogne). Journal of Human Evolution 110: 1-17.

[https://doi.org/10.1016/j.jhevol.2017.04.001].

Reimer PJ, Bard E, Bayliss A, Beck JW, Blackwell PG, Ramsey CB, Buck CE, Cheng H, Edwards, RL, Friedrich M, Grootes PM, Guilderson TP, Haflidason H, Hajdas I, Hatté C, Heaton TJ, Hoffmann DL, Hogg AG, Hughen KA, Kaiser KF, Kromer B, Manning SW, Niu M, Reimer RW, Richards DA, Scott EM, Southon JR, Staff RA, Turney CSM, Plicht J van der. 2013. IntCal13 and Marine13 Radiocarbon Age Calibration Curves 0-50,000 Years cal BP. Radiocarbon 55: 1869-1887. [https://doi.org/10.2458/azu_js_rc.55.16947].

Rofes J. 2018. Datations radiocarbones sur des restes de musaraignes. In Fouille Archéologique de la Grande Rivoire à Sassenage (Isère). Rapport de Fouille 2015-2017, Nicod P-Y, Picavet R (eds.). Lans-en-Vercors; 283-285.

Rofes J, Cucchi T, Hanot P, Herman J, Stephan P, Cersoy S, Horáček I, Kerr E, Allberry K, Valenzuela S, Zazzo A, Cornette R, Tresset A. 2018. Postglacial recolonization and Holocene diversification of Crocidura suaveolens (Mammalia, Soricidae) on the north-western fringe of the European continent. Quaternary Science Reviews 190: 1-10. [https://doi.org/10.1016/j.quascirev.2018.04.016].

Rofes J, Garcia-Ibaibarriaga N, Aguirre M, Martínez-García B, Ortega L, Zuluaga MC, Bailon S, Alonso-Olazabal A, Castaños J, Murelaga X. 2015. Combining Small-Vertebrate, Marine and StableIsotope Data to Reconstruct Past Environments. Scientific Reports 5: 14219.

[https://doi.org/10.1038/srep14219]. 
Rofes J, Murelaga X, Martínez-García B, Bailon S, López-Quintana JC, Guenaga-Lizasu A, Ortega, LÁ, Zuluaga MC, Alonso-Olazabal A, Castaños J, Castaños P. 2014. The long paleoenvironmental sequence of Santimamiñe (Bizkaia, Spain): 20,000 years of small mammal record from the latest Late Pleistocene to the middle Holocene. Quaternary International 339-340: 62-75.

[https://doi.org/10.1016/j.quaint.2013.05.048].

Royer A. 2016. How complex is the evolution of small mammal communities during the Late Glacial in southwest France? Quaternary International 414: 23-33.

[https://doi.org/10.1016/j.quaint.2015.12.065].

Royer A, Sécher A, Langlais M. 2018. A Brief Note on the Presence of the Common Hamster during the Late Glacial Period in Southwestern France. Quaternary 1: 8.

[https://doi.org/10.3390/quat1010008].

Ruff M, Fahrni S, Gäggeler HW, Hajdas I, Suter M, Synal H-A, Szidat S, Wacker L. 2010. On-line Radiocarbon Measurements of Small Samples Using Elemental Analyzer and MICADAS Gas Ion Source. Radiocarbon 52: 1645-1656. [https://doi.org/10.1017/S003382220005637X].

Schoeninger MJ, Moore KM, Murray ML, Kingston JD. 1989. Detection of bone preservation in archaeological and fossil samples. Applied Geochemistry 4: 281-292. [https://doi.org/10.1016/08832927(89)90030-9].

Texier J. 2000. A propos des processus de formation des sites préhistoriques / About prehistoric site formation processes. Paléo, Revue d'Archéologie Préhistorique 12 : 379-386.

[https://doi.org/10.3406/pal.2000.1610].

Van Klinken GJ. 1999. Bone collagen quality indicators for palaeodietary and radiocarbon measurements. Journal of Archaeological Science 26: 687-695.

Wacker L, Němec M, Bourquin J. 2010a. A revolutionary graphitization system: Fully automated, compact and simple. Nuclear Instruments and Methods in Physics Research Section B: Beam Interactions with Materials and Atoms, Proceedings of the Eleventh International Conference on Accelerator Mass Spectrometry 268: 931-934. [https://doi.org/10.1016/j.nimb.2009.10.067]

Wacker L, Bonani G, Friedrich M, Hajdas I, Kromer B, Nemec N, Ruff M, Suter, M, Synal H-A, Vockenhuber C. 2010b. MICADAS: Routine and High-Precision Radiocarbon Dating. Radiocarbon 52: $252-262$.

Wacker L, Fahrni SM, Hajdas I, Molnar M, Synal H-A, Szidat S, Zhang YL. 2013. A versatile gas interface for routine radiocarbon analysis with a gas ion source. Nuclear Instruments and Methods in Physics Research Section B: Beam Interactions with Materials and Atoms, Proceedings of the Twelfth International Conference on Accelerator Mass Spectrometry 294: 315-319.

[https://doi.org/10.1016/j.nimb.2012.02.009].

Wood WR, Lee Johnson D. 1978. 9-A Survey of Disturbance Processes in Archaeological Site Formation. In Advances in Archaeological Method and Theory, Schiffer MB (ed). Academic Press: San Diego; 315-381. [https://doi.org/10.1016/B978-0-12-003101-6.50015-9].

Zazzo A, Lepetz S, Magail J, Gantulga J-O. 2019. High-precision dating of ceremonial activity around a large ritual complex in Late Bronze Age Mongolia. Antiquity 93 (367): 80-98.

[https://doi.org/10.15184/aqy.2018.175]. 


\begin{tabular}{|c|c|c|c|c|}
\hline Lab code & Site & Taxa & Archeological context & $\begin{array}{l}\text { Collagen content } \\
\text { estimation }(w t \%)\end{array}$ \\
\hline JR 27 & Lano & Crocidura suaveolens & Lano 2015 sondage D4 & \\
\hline JR 26 & Lano & Crocidura suaveolens & Lano 2015 sondage D1 & \\
\hline JR 1 & Beg ar Loued & Neomys anomalus & BAL04 SDII H3 p.2 & 7.1 \\
\hline JR 20 & Grande Rivoire & $\begin{array}{l}\text { Sorex } \text { gr. araneus- } \\
\text { coronatus }\end{array}$ & GR05.O17a.d88.LJB (Sect. NR16-21) & \\
\hline JR 21 & Grande Rivoire & $\begin{array}{l}\text { Sorex } \text { gr. araneus- } \\
\text { coronatus }\end{array}$ & GR07.P16a.d111.LBCG (Sect. NR16-21) & \\
\hline JR 18 & Grande Rivoire & $\begin{array}{l}\text { Sorex } \text { gr. araneus- } \\
\text { coronatus }\end{array}$ & GR08.S20d.d22.LGF (Sect. SU16-22) & \\
\hline JR 23 & Grande Rivoire & $\begin{array}{l}\text { Sorex } \text { gr. araneus- } \\
\text { coronatus }\end{array}$ & GR13.Q17c.d142.LBl(B) (Sect. NR16-21) & \\
\hline JR 30 & Grande Rivoire & Crocidura leucodon & GR08.T17b.d28.LGM(F) (Sect. SU16-22) & \\
\hline JR 24 & Grande Rivoire & $\begin{array}{l}\text { Sorex } \text { gr. araneus- } \\
\text { coronatus }\end{array}$ & $\begin{array}{c}\text { GR14.R16b.d143.LGM(C)/CX (Sect. } \\
\text { NR16-21) }\end{array}$ & 8.0 \\
\hline JR 31 & Grande Rivoire & Crocidura suaveolens & $\begin{array}{l}\text { GR14.P17d.d147.GR/LJBl (Sect. NR 16- } \\
\text { 21) }\end{array}$ & \\
\hline JR 13 & Peyrazet & Crocidura russula & PRZ10 M5C d.19 Level 2 & \\
\hline JR 14 & Peyrazet & Crocidura russula & PRZ10 M5C d.20 Level 2 & \\
\hline JR 15 & Peyrazet & Crocidura cf. suaveolens & PRZ09 L6C d.8 Interface Level 3/4 & \\
\hline JR 17 & Peyrazet & Neomys anomalus & PRZ13 L6C d.32 Level 4 & \\
\hline JR 16 & Peyrazet & Neomys anomalus & PRZ12 L6C d.28 Level 4 & 5.2 \\
\hline
\end{tabular}

Table 1. Description of the samples, all of them mandibles of shrews. Collagen preservation in the sample was estimated using ATR-FTIR spectroscopy (see details in the $3^{\text {rd }}$ section of Materials and Methods). 


\begin{tabular}{|c|c|c|c|c|c|c|c|c|c|c|c|}
\hline \multirow[b]{2}{*}{$\begin{array}{l}\text { Lab } \\
\text { code }\end{array}$} & \multirow[b]{2}{*}{ Site } & \multicolumn{3}{|c|}{ Pretreatment } & \multicolumn{4}{|c|}{ Combustion } & \multicolumn{3}{|c|}{ 14C measurement } \\
\hline & & $\begin{array}{c}\text { Sample size } \\
(\mathrm{mg})\end{array}$ & $\begin{array}{c}\text { Collagen } \\
\text { amount } \\
(\mathrm{mg})\end{array}$ & $\begin{array}{c}\text { Yield } \\
(\%)\end{array}$ & $\% \mathrm{C}$ & $\% \mathrm{~N}$ & $\mathrm{C} / \mathrm{N}$ & $\begin{array}{c}\text { Carbon } \\
\text { mass }(\mu \mathrm{gC})\end{array}$ & ECHO n ${ }^{\circ}$ & $\begin{array}{l}\text { 14C age } \\
\text { (BP) }\end{array}$ & Error \\
\hline JR 27 & Lano & 17.8 & 2.7 & 15.2 & 33.1 & 12.0 & 3.2 & 772 & 1252 & -440 & 25 \\
\hline JR 26 & Lano & 25.0 & 3.6 & 14.4 & 33.6 & 12.0 & 3.3 & 862 & 1251 & 515 & 20 \\
\hline JR 13 & Peyrazet & 11.7 & 1.8 & 15.4 & 28.7 & 10.0 & 3.4 & 361 & 1259 & 1585 & 30 \\
\hline JR 14 & Peyrazet & 14.2 & 1.8 & 12.7 & 29.4 & 10.4 & 3.3 & 486 & 1245 & 1475 & 30 \\
\hline JR 1 & Beg ar Loued & 16.2 & 1.5 & 9.3 & 33.7 & 11.9 & 3.3 & 391 & 1258 & 3650 & 30 \\
\hline JR 20 & Grande Rivoire & 12.0 & 1.3 & 10.8 & 29.1 & 10.0 & 3.4 & 309 & 1262 & 5070 & 40 \\
\hline JR 21 & Grande Rivoire & 15.0 & 1.7 & 11.3 & 29.1 & 10.3 & 3.3 & 433 & 1256 & 5760 & 40 \\
\hline JR 18 & Grande Rivoire & 11.5 & 1.0 & 8.7 & 26.6 & 8.5 & $3.6^{*}$ & 188 & 1261 & 6410 & 45 \\
\hline JR 23 & Grande Rivoire & 10.8 & 1.4 & 13.0 & 31.3 & 10.6 & 3.4 & 232 & 1260 & 6510 & 40 \\
\hline JR 30 & Grande Rivoire & 10.5 & 0.9 & 8.6 & 18.4 & 6.1 & $3.5^{*}$ & 390 & 1702 & 6750 & 50 \\
\hline JR 24 & Grande Rivoire & 15.9 & 1.1 & 6.9 & 22.8 & 7.9 & 3.4 & 357 & 1247 & 7130 & 40 \\
\hline JR 31 & Grande Rivoire & 12.9 & 0.7 & 5.4 & 19.8 & 6.5 & $3.6^{*}$ & 323 & 1696 & 7600 & 50 \\
\hline JR 15 & Peyrazet & 12.3 & 0.4 & 3.3 & 15.5 & 5.4 & 3.3 & 174 & 1633 & 11790 & $230 * *$ \\
\hline JR 17 & Peyrazet & 15.6 & 1.2 & 7.7 & 24.3 & 8.4 & 3.4 & 231 & 1253 & 12940 & 70 \\
\hline JR 16 & Peyrazet & 22.8 & 0.7 & 3.1 & 30.7 & 10.2 & $3.5^{*}$ & 266 & 1254 & 12960 & 70 \\
\hline
\end{tabular}

Table 2. Radiocarbon dating of the shrew samples. Yield is estimated as the ratio (in \%) of the total amount of collagen recovered from the amount of initial bone used for extraction. The carbon mass corresponds to the amount of carbon detected following combustion in the Elemental Analyzer and used to produce the graphite target. ECHo $\mathrm{n}^{\circ}$ corresponds to the target numbers. *Four dates (three from Grande Rivoire and one from Peyrazet) appear to have a $\mathrm{C} / \mathrm{N}$ ratio equal to or higher than 3.5. **Due to the low amount of collagen for this sample (JR 15), 14C content was measured via a gas interface system (GIS) which explains the higher value of the error on the $14 \mathrm{C}$ age. 


\begin{tabular}{|c|c|c|c|c|c|c|c|}
\hline Site & $\begin{array}{c}\text { Cultural } \\
\text { attribution }\end{array}$ & Context & Lab code & Element & 14C date $(\mathrm{BP})$ & $\begin{array}{l}\text { 2-Sigma cal } \\
\text { BP }\end{array}$ & $\begin{array}{c}\text { 2-Sigma cal AD- } \\
\text { BC }\end{array}$ \\
\hline \multirow{13}{*}{ Peyrazet } & \multirow{2}{*}{ Early Middle Age } & Unit 2 & ECHo-1259 (JR 13) & Shrew mandible & $1585 \pm 30$ & $1407-1542$ & AD $408-543$ \\
\hline & & Unit 2 & ECHo-1245 (JR 14) & Shrew mandible & $1475 \pm 30$ & $1307-1407$ & AD 543-643 \\
\hline & Recent Laborian & Unit 2 & Ly-7828 (SacA-22775) & Red deer bone & $9780 \pm 45$ & $11257-11141$ & BC 9308-9192 \\
\hline & \multirow{2}{*}{$\begin{array}{c}\text { Upper } \\
\text { Magdalenian/Azilian }\end{array}$} & $\begin{array}{c}\text { Interface between } \\
\text { units } 3 \text { and } 4\end{array}$ & ECHo-1634 (JR 15) & Shrew mandible & $11790 \pm 230$ & $14175-13129$ & BC 12226-11180 \\
\hline & & $\begin{array}{c}\text { Interface between } \\
\text { units } 3 \text { and } 4\end{array}$ & Ly-7826 (SacA-22773) & Roe deer bone & $11810 \pm 50$ & $13756-13541$ & BC 11807-11592 \\
\hline & \multirow{7}{*}{ Upper Magdalenian } & Unit 4 & Ly-6437 (SacA-17857) & Reindeer bone & $12580 \pm 80$ & $15208-14402$ & BC 13259-12453 \\
\hline & & Unit 4 & Ly-6436 (SacA-17856) & Reindeer bone & $12720 \pm 80$ & $15405-14776$ & BC 13456-12827 \\
\hline & & Unit 4 & $\begin{array}{c}\text { Ly-13448 (Sac- } \\
\text { A47545) }\end{array}$ & Chamois bone & $12810 \pm 60$ & $15536-15091$ & BC 13587-13142 \\
\hline & & Unit 4 & $\begin{array}{c}\text { Ly-13447 (SacA } \\
47544)\end{array}$ & Reindeer bone & $12840 \pm 60$ & $15574-15126$ & BC 13625-13177 \\
\hline & & Unit 4 & ECHo-1253 (JR 17) & Shrew mandible & $12940 \pm 70$ & $15731-15228$ & BC 13782-13279 \\
\hline & & Unit 4 & $\begin{array}{c}\text { Ly-11974 (Sac- } \\
\text { A40416) }\end{array}$ & Water vole bones & $12960 \pm 70$ & $15752-15249$ & BC 13803-13300 \\
\hline & & Unit 4 & ECHo-1254 (JR 16) & Shrew mandible & $12960 \pm 70$ & $15752-15249$ & BC 13803-13300 \\
\hline & pre-Bølling & Unit 5 & Ly-11975 (SacA40417) & Water vole bones & $13540 \pm 80$ & $16599-16052$ & BC 14650-14103 \\
\hline \multirow{2}{*}{$\begin{array}{l}\text { Beg ar } \\
\text { Loued }\end{array}$} & Middle Bronze Age & $\begin{array}{l}\text { SDII G/H/I3 } \\
\text { US2004 }\end{array}$ & UB-6925 & Vole mandible & $3177 \pm 35$ & $3467-3342$ & BC 1518-1393 \\
\hline & Early Bronze Age & SDII H3 p. 2 & ECHo-1258 (JR 1) & Shrew mandible & $3650 \pm 30$ & $4014-3888$ & BC 2065-1939 \\
\hline \multirow{4}{*}{ Lano } & \multirow[b]{2}{*}{ Modern } & D4 & ECHo-1252 (JR 27) & Shrew mandible & $-440 \pm 25$ & $-4-0$ & AD 1956-1957 \\
\hline & & D5 & Poz-81616 & $\begin{array}{c}\text { Small vertebrate } \\
\text { bones }\end{array}$ & $-100 \pm 26$ & $-4-0$ & AD 1955-1956 \\
\hline & Late Middle Age & D1 & ECHo-1251 (JR 26) & Shrew mandible & $515 \pm 20$ & $512-547$ & AD 1403-1438 \\
\hline & Early Middle Age & D3 & Poz-81615 & $\begin{array}{c}\text { Small vertebrate } \\
\text { bones }\end{array}$ & $1155 \pm 30$ & $1042-1175$ & AD 775-908 \\
\hline
\end{tabular}

Table 3. Radiocarbon dates (selection) for the Peyrazet, Beg ar Loued and Lano archaeological sites, including those recently obtained in this study from shrew mandibles (shaded). All radiocarbon dates were calibrated using the software Calib Rev 7.0.0 and the Intcal13 calibration curve. "Context" refers to the archaeological layers where the remains were found. The layers follow a chrono-stratigraphical order from bottom to top including an "stratigraphic inversion" for Lano (details given in the Results section). For taxonomical attribution of the shrew mandibles see Table 1. 


\begin{tabular}{|c|c|c|c|c|c|c|}
\hline \multicolumn{7}{|l|}{ Area Nr16-21 } \\
\hline Cultural attribution & Context & Lab code & Element & $\begin{array}{c}\text { 14C date } \\
\text { (BP) }\end{array}$ & 2-Sigma cal BP & 2-Sigma cal BC \\
\hline \multirow{3}{*}{ Late Neolithic } & \multirow{2}{*}{$\mathrm{d} 85$} & Lyon-4418 (SacA-8120) & Charcoal & $4705 \pm 35$ & $5582-5322$ & $3632-3372$ \\
\hline & & Lyon-7342 (SacA-20960) & Cornus seed & $4715 \pm 35$ & $5582-5325$ & $3632-3375$ \\
\hline & $\mathrm{d} 87$ & Lyon-7343 (SacA-20961) & Charcoal & $4610 \pm 30$ & $5460-5146$ & $3510-3196$ \\
\hline \multirow{4}{*}{ Middle Neolithic 2} & \multirow[t]{2}{*}{$\mathrm{d} 88$} & ECHo-1262 (JR 20) & Shrew mandible & $5070 \pm 40$ & $5912-5728$ & $3962-3778$ \\
\hline & & Lyon-4407 (SacA-8109) & Charcoal & $5110 \pm 30$ & $5925-5750$ & $3975-3800$ \\
\hline & $\mathrm{d} 92$ & Lyon-4409 (SacA-8111) & Charcoal & $5055 \pm 35$ & $5908-5723$ & $3958-3773$ \\
\hline & $\mathrm{d} 96$ & Lyon-4411 (SacA-8113) & Charcoal & $5075 \pm 35$ & $5911-5742$ & $3961-3792$ \\
\hline \multirow{6}{*}{ Middle Neolithic 1} & $\mathrm{~d} 108$ & Lyon-4422 (SacA-8124) & Charcoal & $5700 \pm 35$ & $6620-6406$ & $4670-4456$ \\
\hline & d109 & Lyon-4423 (SacA-8125) & Charcoal & $5645 \pm 35$ & $6496-6320$ & $4546-4370$ \\
\hline & $\mathrm{d} 110$ & Lyon-4424 (SacA-8126) & Charcoal & $5790 \pm 35$ & $6670-6497$ & $4720-4547$ \\
\hline & \multirow[t]{2}{*}{$\mathrm{d} 111$} & ECHo-1256 (JR 21) & Shrew mandible & $5760 \pm 40$ & $6659-6454$ & $4709-4504$ \\
\hline & & Lyon-12108 (SacA-41854) & Charcoal & $5790 \pm 40$ & $6713-6486$ & $4763-4536$ \\
\hline & $\mathrm{d} 115$ & Lyon-7347 (SacA-20965) & Charcoal & $5805 \pm 35$ & $6716-6498$ & $4766-4548$ \\
\hline \multirow{5}{*}{ Early Neolithic } & \multirow[t]{2}{*}{$\mathrm{d} 140$} & Lyon-13969 (SacA-49309) & Charcoal & $6145 \pm 35$ & $7161-6950$ & $5211-5000$ \\
\hline & & Lyon-11551 (SacA-39068) & Bone & $6415 \pm 40$ & $7422-7275$ & $5472-5325$ \\
\hline & \multirow[t]{3}{*}{$\mathrm{d} 142$} & Lyon-11552 (SacA-39069) & Red deer bone & $6490 \pm 35$ & $7467-7321$ & $5517-5371$ \\
\hline & & ECHo-1260 (JR 23) & Shrew mandible & $6510 \pm 40$ & $7492-7323$ & $5542-5373$ \\
\hline & & Lyon-13970 (SacA-49310) & Charcoal & $6865 \pm 35$ & $7787-7621$ & $5837-5671$ \\
\hline \multirow{4}{*}{ Second Mesolithic } & \multirow[t]{2}{*}{$\mathrm{d} 143$} & Lyon-13971 (SacA-49311) & Charred hazelnut & $6815 \pm 35$ & $7698-7587$ & $5748-5637$ \\
\hline & & ECHo-1247 (JR 24) & Shrew mandible & $7130 \pm 40$ & $8019-7865$ & $6069-5915$ \\
\hline & \multirow[t]{2}{*}{$\mathrm{d} 147$} & Lyon-13972 (SacA-49312) & Charred hazelnut & $7315 \pm 40$ & $8191-8021$ & $6241-6071$ \\
\hline & & ECHo-1696 (JR 31) & Shrew mandible & $7600 \pm 50$ & $8536-8334$ & $6586-6384$ \\
\hline
\end{tabular}




\begin{tabular}{|c|c|c|c|c|c|c|}
\hline \multicolumn{7}{|l|}{ Area SU16-21 } \\
\hline $\begin{array}{c}\text { Cultural } \\
\text { attribution }\end{array}$ & Context & Lab code & Element & $\begin{array}{c}\text { 14C date } \\
\text { (BP) }\end{array}$ & 2-Sigma cal BP & 2-Sigma cal BC \\
\hline Early Neolithic & $\mathrm{d} 22$ & ECHo-1261 (JR 18) & Shrew mandible & $6410 \pm 45$ & $7422-7268$ & $5472-5318$ \\
\hline \multirow{4}{*}{$\begin{array}{c}\text { Early } \\
\text { Neolithic/Second } \\
\text { Mesolithic }\end{array}$} & $\mathrm{d} 26$ & Beta- 282246 & Red deer bone & $6510 \pm 40$ & $7496-7324$ & $5546-5374$ \\
\hline & \multirow[t]{3}{*}{$\mathrm{d} 28$} & Beta- 255118 & Red deer bone & $6430 \pm 50$ & $7428-7269$ & $5478-5319$ \\
\hline & & Beta-282247 & Red deer bone & $6490 \pm 40$ & $7477-7317$ & $5527-5367$ \\
\hline & & ECHo-1702 (JR 30) & Shrew mandible & $6750 \pm 50$ & $7680-7514$ & $5730-5564$ \\
\hline \multirow[t]{2}{*}{ Second Mesolithic } & $\mathrm{d} 30$ & Beta-255119 & Red deer bone & $7310 \pm 40$ & $8187-8022$ & $6237-6072$ \\
\hline & $\mathrm{d} 34$ & Beta-282248 & Red deer bone & $7790 \pm 40$ & $8638-8456$ & $6688-6506$ \\
\hline
\end{tabular}

Table 4. Radiocarbon dates for the Grande Rivoire archaeological site, including those recently obtained in this study from shrew mandibles (shaded). All radiocarbon dates were calibrated using the software Calib Rev 7.0.0 and the Intcal13 calibration curve. "Context" refers to the arbitrary archaeological layers (d: décapage) where the remains were found. The layers follow a chrono-stratigraphical order from bottom to top in both areas (Nr16-21 and SU1621). For taxonomical attribution of the shrew mandibles see Table 1. 


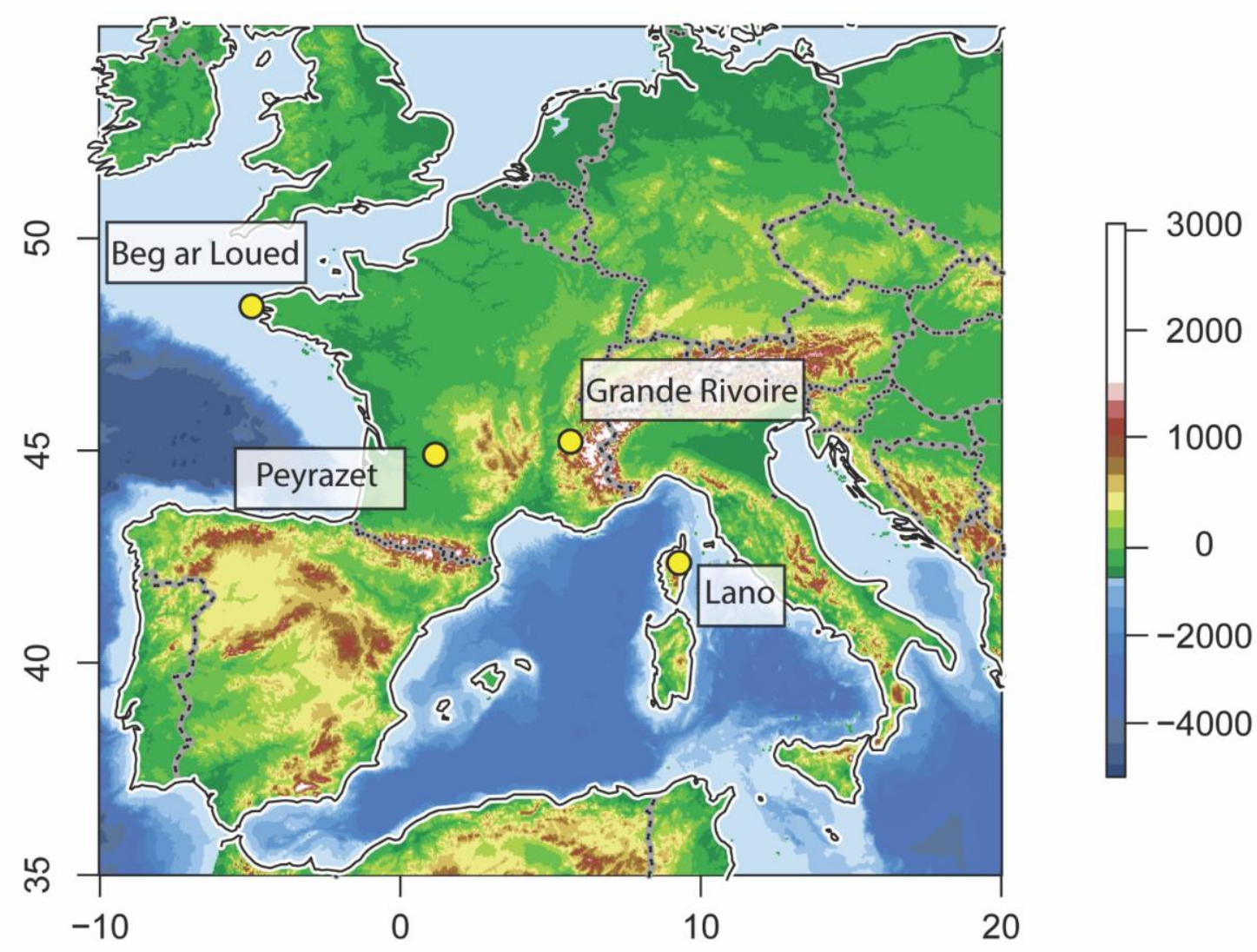

Figure 1. Location of the archaeological sites. 


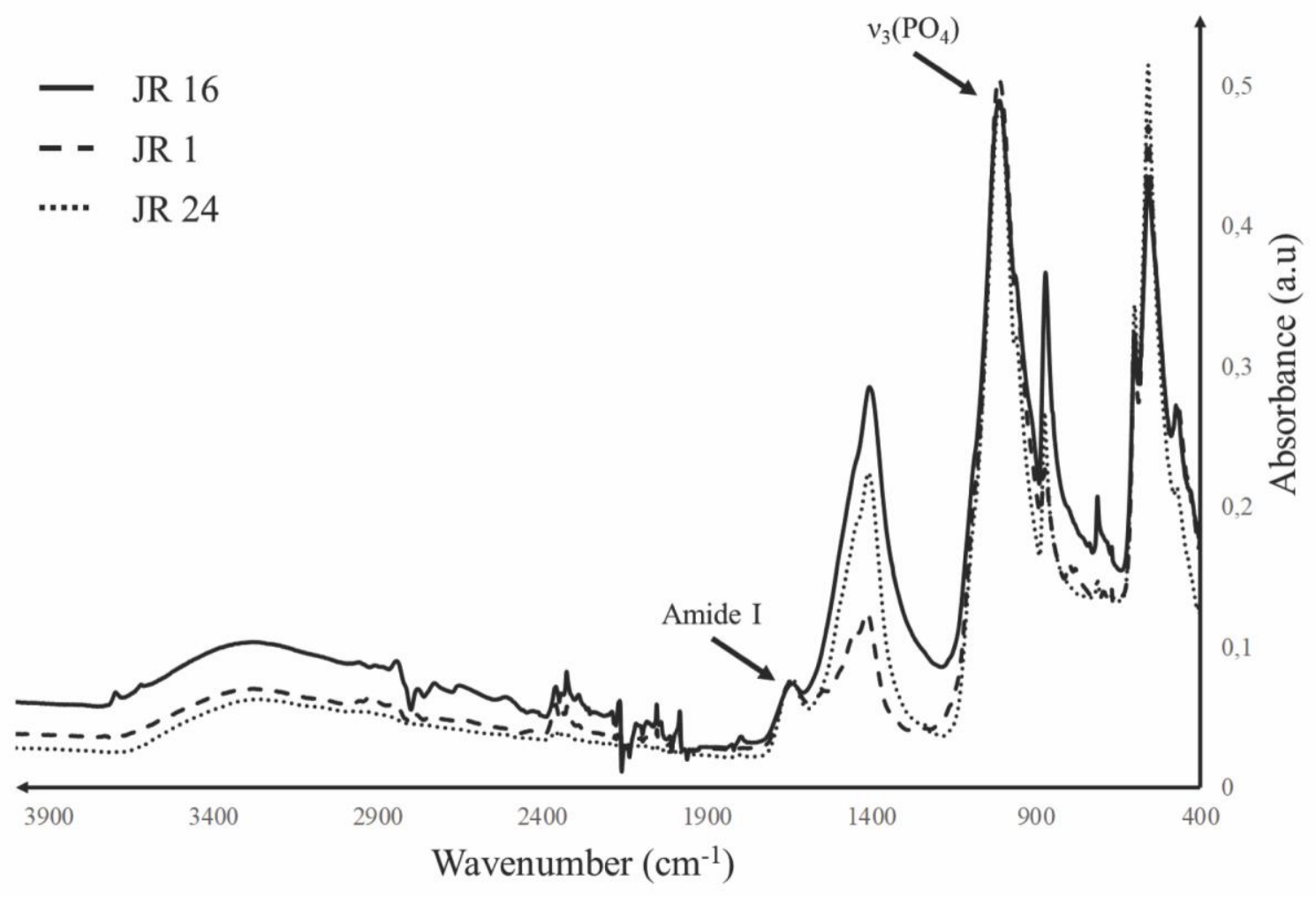

Figure 2. Prescreening ATR-FTIR spectra of selected shrew bone samples: Neomys anomalus from Peyrazet (JR 16), Sorex gr. araneus-coronatus from Grande Rivoire (JR 24) and Neomys anomalus from Beg ar Loued (JR 1). The two bands of interest for collagen preservation study $\left[v_{3}\left(\mathrm{PO}_{4}\right)\right.$ mineral and amide I organic bands] are indicated by arrows. 


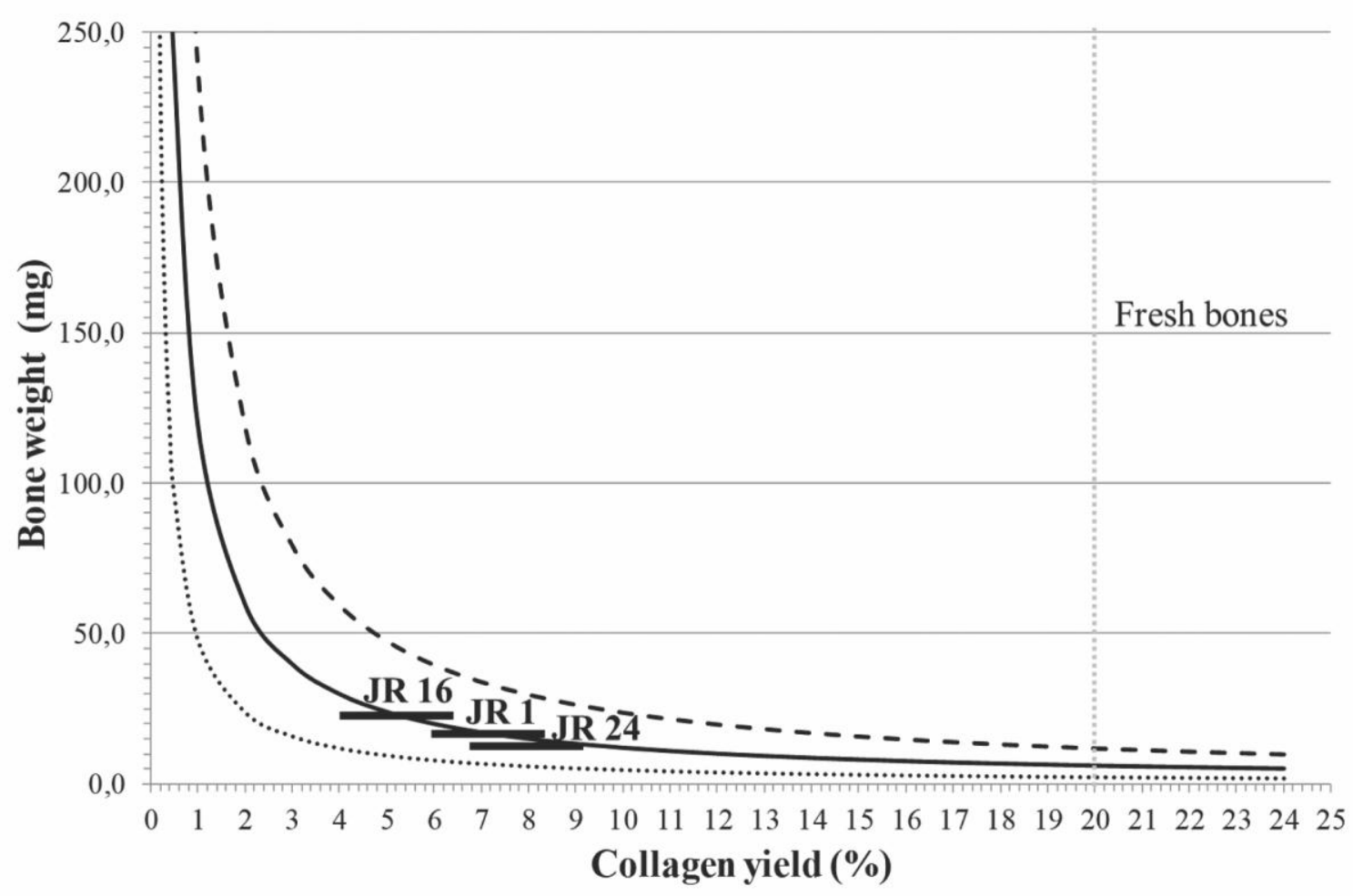

Figure 3. Radiocarbon dating feasibility chart based on the carbon concentration in bone collagen (40\%). Y-axis corresponds to the minimum bone weight needed for a reliable radiocarbon date. Xaxis corresponds to the collagen content within the bone as estimated by FTIR. Dotted line: to obtain $0.2 \mathrm{mgC}$. Solid line: $0.5 \mathrm{mgC}$. Dashed line: conventional $1 \mathrm{mgC}$. Samples JR 16, JR 1 and JR 24 are reported on the chart, considering the standard error for FTIR estimation $( \pm 1.2 \%)$. 


\section{A}

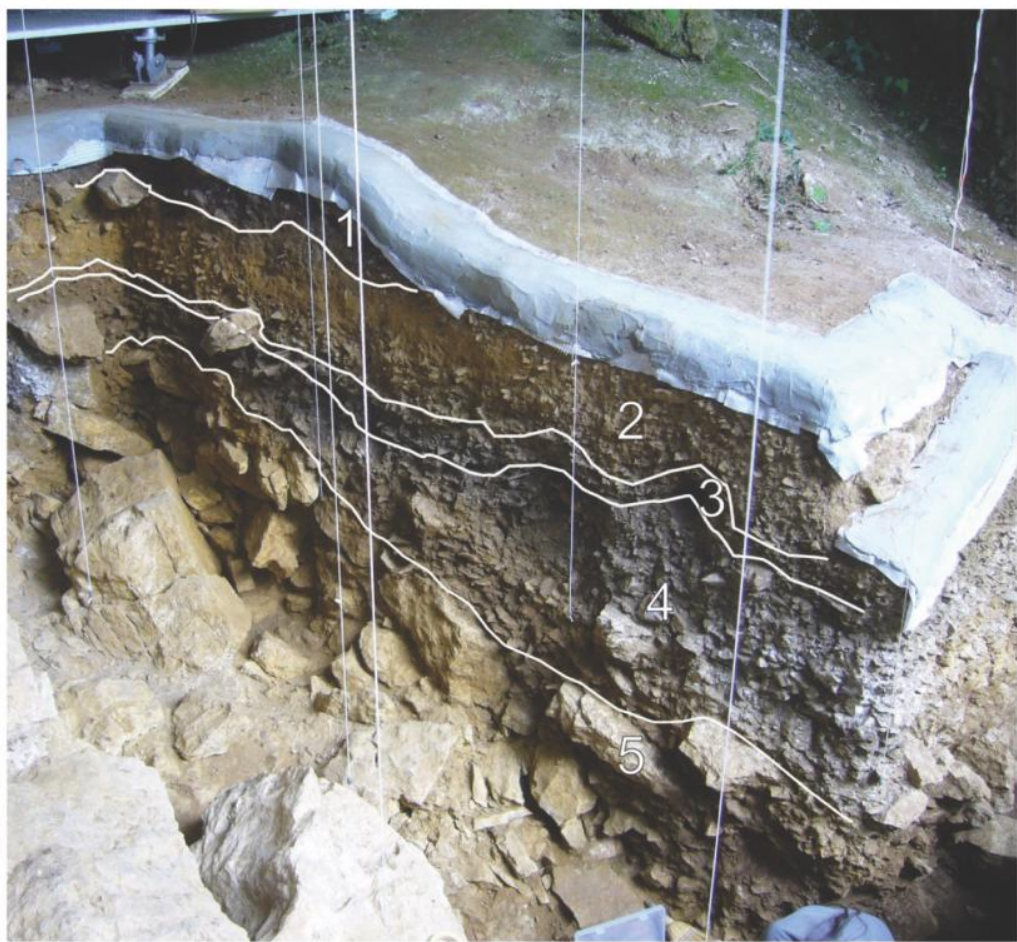

Unit 1 :

Modern and Laborian

Unit 2 :

Laborian

Unit 3:

Azilian

Unit 4 :

Upper

Magdalenian

Unit 5 :

Roof caving

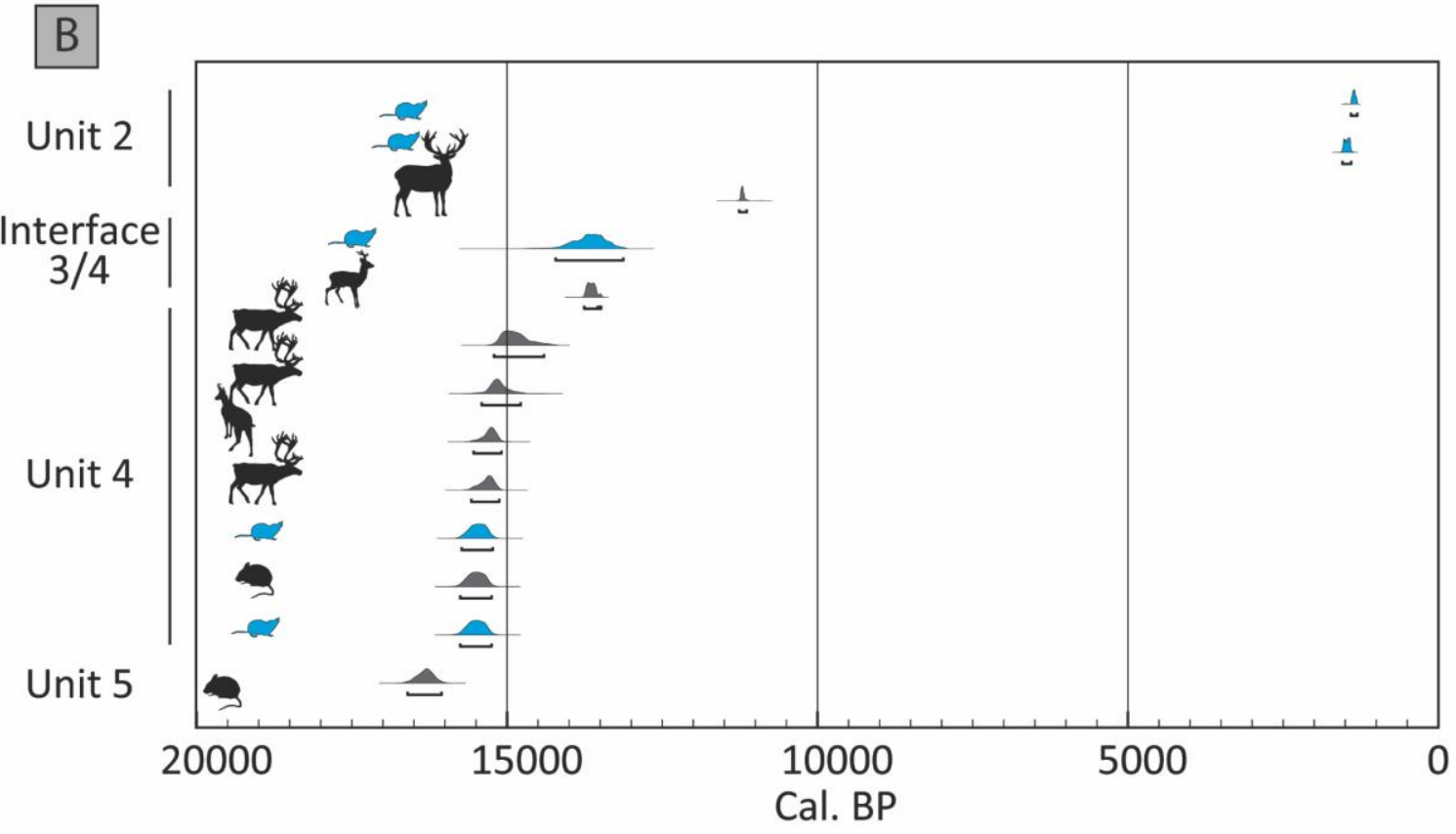

Figure 4. (A) Archaeological profile of Peyrazet showing the chrono-cultural stratigraphic units. (B) Synthesis of the radiocarbon dates discussed in the text, including those newly obtained from shrews (blue) and those from other large and small mammals (black). 